\title{
A viola na sociedade oitocentista carioca e o baixo contínuo
}

\author{
Luciana Câmara Queiroz de Souza, Andréa Alencar Coelho da Silva \\ Universidade Federal de Pernambuco | Brasil
}

\begin{abstract}
Resumo: O presente estudo tem por objetivo discutir aspectos da presença da viola, do ponto de vista sociocultural e da prática musical, no Rio de Janeiro do início do século XIX. Trata-se de estudo bibliográfico baseado em literatura sobre a vida musical na cidade no período de 1750 a 1850 e no estudo de fontes de época em torno da viola, principalmente em relação ao baixo contínuo e ao acompanhamento. Destacam-se na análise sociocultural o conflito entre aceitação e preconceito em relação ao instrumento e seus tocadores; e a presença do instrumento na instrução musical. A partir do exemplo da Arte de muzica (Anônimo, 1823) considera-se que o instrumento possivelmente era usado na instrução musical básica e que a versão simplificada da regra da oitava apresentada pelo autor poderia exemplificar uma junção das práticas oral e escrita da época.
\end{abstract}

Palavras-chave: Viola (instrumento de cordas dedilhadas), Baixo contínuo, Acompanhamento, Modinha.

\begin{abstract}
The aim of this study is to discuss, from socio-cultural and music practice perspectives, the presence of the viola (guitar) in Rio de Janeiro at the beginning of the nineteenth century. This bibliographical study is based on literature about the musical life in Brazil from 1750 to 1850, and the study of period sources about the viola, particularly in relation to thorough bass and accompaniment. Issues that stand out from the socio-cultural analysis are the conflict between acceptance and prejudice in relation to the instrument and its performers, and the use of the instrument for music instruction. We consider, taking as a departure point the example given by the Arte de muzica (Anonymous, 1823), that the instrument was conceivably used during early musical instruction and that a simplified version of the rule of the octave, proposed by its author, might epitomize a confluence of oral and written practices of the period.
\end{abstract}

Keywords: Viola (guitar), Thoroughbass, Accompaniment, Modinha 


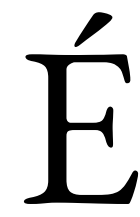

amplamente conhecida a informação de que José Maurício Nunes Garcia (1767-1830) tocava viola e lecionava música usando uma viola de arame (AZEVEDO, 1877, p. 323; MATTOS, 1997, p. 30 e 45). Deve-se considerar, portanto, que as práticas da época em instrumentos de cordas dedilhadas possivelmente tiveram papel importante na produção de José Maurício. Se se quer compreender melhor o fazer musical deste que é tido como um dos mais importantes compositores brasileiros, faz-se necessário analisar a presença da viola e de instrumentos similares no Rio de Janeiro das últimas décadas do século XVIII e primeira metade do XIX. Este artigo, que é parte de um projeto mais amplo de estudo da produção musical de José Maurício, tendo como foco principal seu Methodo de piano-forte (Rio de Janeiro, 1821), discute alguns aspectos do papel sociocultural e da prática musical em torno da viola no período. ${ }^{1}$

Apesar da já bem conhecida ligação entre José Maurício e a viola, estabelecer o possível papel da viola na prática musical do padre mestre não é tarefa simples. José Maurício era amplamente reconhecido como instrumentista de teclas. ${ }^{2}$ Ainda assim, o único repertório de teclas de sua autoria conhecido atualmente é seu Methodo. ${ }^{3}$ Além disso, o tipo de repertório notado ao qual José Maurício majoritariamente se dedicou, a música sacra, não inclui instrumentos de cordas dedilhadas em sua instrumentação. Os gêneros musicais com partes notadas para viola e similares são geralmente danças e modinhas. ${ }^{4}$ José Maurício compôs modinhas, mas, infelizmente, as únicas que se conhecem foram publicadas depois de sua morte..$^{5}$ Apesar de tantas lacunas, há um campo de interseção entre instrumentos de cordas dedilhadas e de teclas. Ambos, neste período, têm em comum a prática do baixo contínuo e do acompanhamento. Não por acaso o repertório mais frequentemente partilhado por esses dois grupos de instrumentos é justamente o de danças e modinhas. As práticas de acompanhamento e baixo contínuo são, portanto, um dos focos de nossa discussão.

A análise empreendida aqui está baseada em literatura sobre a vida musical no Rio de Janeiro no período de 1750 a 1850, mais especificamente sobre instrumentos de cordas dedilhadas e sobre a

\footnotetext{
${ }^{1}$ Este projeto envolveu também a elaboração de duas propostas de realização do baixo de uma lição do Methodo para violão moderno. As propostas de realização do contínuo são objeto de outra publicação.

${ }^{2}$ Tecladistas neste período tocavam diferentes instrumentos de tecla: cravo, fortepiano, órgão e clavicórdio.

${ }^{3}$ Para um estudo com edição facsimilar do Mebtodo, ver Fagerlande (1995). Para uma análise das possibilidades de ornamentação e livre improvisação do Mebtodo, ver Barroso (2006). Para um apanhado da produção conhecida de José Maurício para teclas ver Trilha (2019).

${ }^{4}$ Ver o repertório discutido em Budasz (2001) e Nogueira (2008).

${ }^{5}$ Para um levantamento crítico das modinhas conhecidas de José Maurício ver Pacheco (2019).
} 
prática do baixo contínuo no Brasil. Dois documentos centrais em nossa discussão são a Nova Arte de viola, de Manoel da Paixão Ribeiro (Coimbra, 1789) e a Arte de muzica para uso da mocidade

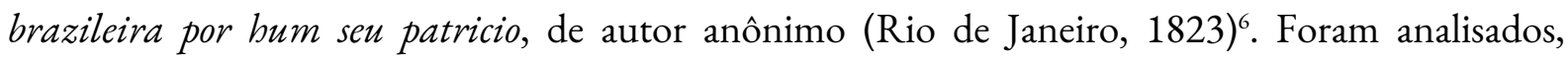
também, exemplos musicais de acompanhamentos para cordas dedilhadas. Procuramos compreender como era a prática com instrumentos de cordas dedilhadas no período de vida de José Maurício, quais seriam os locais e os atores dessa prática e quais seriam as especificidades do baixo contínuo e do acompanhamento nestes instrumentos.

Cabe ainda ressaltar que a narrativa histórica neste estudo está baseada em uma visão de tempo histórico na qual se trabalha com três níveis de significação dos fenômenos estudados: significados residuais, atuais e latentes. Todo fenômeno pode apresentar, em diferentes graus, significados derivados de eventos cronologicamente anteriores (residuais), significados elaborados em seu momento mesmo de existência (atuais) e significados que alcançarão plena realização num momento futuro (latentes) (FREIRE, 1994). Entendemos, assim, o jogo de tensóes e sínteses inerentes à existência dos instrumentos de cordas dedilhadas no Rio de Janeiro da época de José Maurício como temporalmente dinâmico e multifacetado.

\section{Viola: aspectos da história sociocultural do instrumento}

Nas fontes do período estudado aqui nem sempre é possível definir com exatidão a qual instrumento de cordas dedilhadas se referem termos como viola e guitarra (ou guitar em inglês e Guitarre em alemão). Sabe-se que do século XVI ao XVIII o termo viola podia referir-se a um instrumento de quatro, seis (vihuela) ou cinco ordens (guitarra barroca) e que este último, muito popular no século XVIII, está na origem da viola caipira brasileira e do violão de seis cordas, além de alguns tipos de violas portuguesas (BUDASZ, 2007, p. 6). Pelo menos na primeira metade do século XIX o termo viola segue sendo usado para designar tanto o instrumento do século XVIII, que permanece, quanto o instrumento que progressivamente se aproxima do que chamamos hoje em dia de violão moderno. Essa proximidade da viola de cinco ordens e do violão está inclusive expressa na

\footnotetext{
${ }^{6}$ Deixamos aqui nosso agradecimento a Marcelo Fagerlande que gentilmente nos cedeu uma cópia digitalizada da fotocópia que ele tem do original da Arte. O original está depositado na Biblioteca Nacional sob o número 51.57.79.
} 
designação viola francesa, usada em Portugal e no Brasil na primeira metade do século XIX para a viola de seis cordas simples, e do próprio termo violão, adotado ao longo do segundo quarto deste século e que significa, literalmente, viola grande (BUDASZ, 2015, p. 81, nota 14).7

Dois trabalhos dedicados à classificação dos instrumentos de cordas dedilhadas em uso no Brasil dos séculos XVIII e XIX dão ideia da complexidade do tema. Castro (2016), em sua proposta de classificação organológica da viola e do violão no Rio de Janeiro no período, argumenta que uma classificação tendo como eixo as discrepâncias na organologia da viola e do violão é útil para reduzir as ambiguidades constantes na literatura e documentos sobre os instrumentos de cordas dedilhadas. $\mathrm{O}$ autor defende ainda que as fontes documentais sobre a viola e o violão sejam igualmente apresentadas de forma comparativa, a fim de fornecer não só uma cronologia, mas também uma visão abrangente dos contextos e tipos de publicação nos quais as referências aos dois instrumentos aparecem. A proposta de Castro certamente permite uma visão concisa e ao mesmo tempo detalhada da situação da viola e do violão nos documentos que temos a nosso dispor. Vale ressaltar que outros termos empregados para designar instrumentos de cordas dedilhadas em circulação no período ficam, por força, de fora da classificação. Esse fato é especialmente problemático quando nos deparamos com fontes como a Arte de muzica que, em 1823, usa o termo guitarra. Castro documenta o uso das palavras guitarre franceza (1866) e guitarras e violóes (1877), nos dois casos em período muito posterior ao da publicação da Arte, quando já podem ser claramente associados ao violão.

Já Ballesté (2009) elabora uma organização conceitual dos instrumentos de cordas dedilhadas luso-brasileiros baseada na terminologia empregada em dicionários e métodos para instrumentos de cordas dedilhadas em língua portuguesa publicados entre 1789 e 1899. Uma rede ampla de conceitos, termos técnicos e colocaçôes de ordem estética ou sociocultural, tais como "Em Portugal era o Instrumento favorito das Damas” (referindo-se à guitarra, p. 292), fornece um quadro conceitual abrangente sobre os instrumentos. Esse quadro é apresentado por meio de fichas descritivas das fontes consultadas, dos instrumentos musicais e de detalhes da construção dos mesmos. As fontes documentais levantadas por Ballesté incluem a Nova arte de viola, de Ribeiro e o Compendio de

\footnotetext{
${ }^{7}$ Para uma análise dos diferentes instrumentos de cordas dedilhadas em circulação em Portugal e no Brasil no século XVIII e XIX ver Budasz (2001, especialmente páginas 31-45), Nogueira (2008, p.16-28) e Castro (2014, p. 138-144).
} 
musica, de Domingos Varella (Porto, 1806), dos quais falaremos adiante, mas não incluem a Arte de muzica, deixando de fora a referência que essa fonte faz à guitarra.

Trataremos aqui dos instrumentos de cordas dedilhadas, compreendendo que, na maioria das vezes, a documentação se refere à viola de cinco (posteriormente seis) ordens. A viola parece ter sido o instrumento mais difundido na época no Rio de Janeiro (TABORDA, 2011b, p. 53-57; CASTRO, 2014, p. 15-16). Além disso, ou talvez por essa razão, é o instrumento associado a José Maurício. Assumimos, portanto, que a Arte de muzica utiliza o termo guitarra para referir-se à viola e não à guitarra portuguesa.

Ao discutirmos conjuntamente a viola/violão evitamos uma visão de continuidade evolutiva entre esses dois instrumentos. Ballesté (2009) e Castro (2016) demonstram que nem sempre é possível uma diferenciação estrita dos dois, pelo menos na primeira metade do século XIX. Consideramos, isso sim, que há a manutenção de certas práticas, como o acompanhamento de cançôes e a prática do baixo contínuo, já seja no instrumento de cinco ordens duplas, já seja no de seis cordas simples. Os atores e espaços dessas práticas são tão importantes quanto a terminologia ou as especificidades de construção do instrumento para compreendermos melhor a viola em toda a sua diversidade. Conscientes, contudo, dessa imprecisão terminológica faremos referência a ela quando necessário.

A rede simbólica em torno dos instrumentos de cordas dedilhadas é ampla e complexa. Um ponto conflitivo a ser considerado em qualquer discussão sobre o papel da viola na sociedade carioca do período é o da oposição entre preconceito e aceitação social. Como foi dito acima, a viola era extremamente popular e estava amplamente difundida. Contudo, a literatura reporta recorrentemente o preconceito em relação ao instrumento e aos seus tocadores (BUDASZ, 2001, p. 65-66; NOGUEIRA, 2008, p. 38-45). Nesse sentido, um exemplo a ser comentado aqui é o da associação entre negros escravizados e o instrumento no período de 1808 a 1830 . Segundo Amorim as violas e demais instrumentos de cordas dedilhadas podiam ser encontrados com frequência nas mãos dos escravizados ao longo de todo o período (AMORIM, 2017a, p. 102-103). O autor levanta diversos nomes de pessoas escravizadas que eram tocadoras de viola, sendo todas elas fugitivas que estavam sendo procuradas por seus senhores através de anúncios em jornais que ofereciam recompensa a quem os encontrasse. A menção às habilidades musicais de escravizados servia para facilitar sua busca, já que a música ocupava um papel secundário na vida dos mesmos. Alguns 
exemplos levantados por Amorim, todos anunciados em jornais do Rio de Janeiro: o mulato Telesforo - bolieiro e tocador de guitarra; crioulo Antônio, que fugira apenas com a roupa do corpo e "uma viola pequena que tocava"; pardo Benedito, oficial de alfaiate e "tocador de viola"; Joze Custódio, "ourives e carpinteiro, [...] tomava tabaco e tocava viola” (AMORIM, 2017a, p. 106). Para o autor, estes anúncios são exemplos de associação pejorativa entre a música, os negros e seus instrumentos musicais. Amorim considera que quando há menção à habilidade musical e/ou ao instrumento musical dos escravizados, esta é depreciativa, pois vem acompanhada de hábitos considerados vícios.

Mas há também relatos de fins do século XVIII e início do XIX de uso de instrumentos de cordas dedilhadas pelos cidadãos livres no espaço doméstico urbano (STAUNTON, 1797; SPIX; MARTIUS, 1854; SILVA, 2015) e em anúncios de ensino de música (AMORIM, 2017b). No caso dos exemplos testemunhados por Staunton e por Spix e Martius, os autores usam os termos guitar e Guitarre (viola), respectivamente. Staunton relata que nos lares do Rio de Janeiro as senhoras "se divertiam à noite tocando algum instrumento musical, principalmente o cravo ou a viola.” (STAUNTON, 1797, p. 161. Tradução nossa.) $)^{8}$ Spix e Martius, comentando o gosto apurado dos brasileiros para a música, especialmente no Rio de Janeiro, relatam a predileção pelo acompanhamento simples à viola e acrescentam que este instrumento “... é aqui [no Brasil], como no sul da Europa, o instrumento preferido [das pessoas]; o fortepiano, ao contrário, é um móvel raro, sendo encontrado apenas nas casas dos mais ricos.” (SPIX; MARTIUS, 1854, p. 54. Tradução nossa.) $)^{9}$

Já na alta sociedade, aquela em condições de ter um fortepiano em casa, a viola ou violão também figurava. Nesse sentido, vale mencionar o caso da família suíça Däniker-Haller, cuja prática de música doméstica é objeto do estudo de Silva (2015). O violão era um dos instrumentos preferidos de Cécile Däniker-Haller que, juntamente com seu esposo Henrich Däniker-Haller, realizava seróes musicais em sua casa no Rio de Janeiro, na primeira metade do século XIX. ${ }^{10}$ Nos diários da família

\footnotetext{
8 "They [the ladies] amused themselves, in the evenings, in playing on some kind of musical instrument, chiefly the harpsichord or guitar.” Traduzimos guitar como viola para usarmos o termo genérico nas duas linguas.

9 "Der Brasilianer hat mit dem Portugiesen einen feinen Sinn für angenehme Modulation und regelmässige Fortschreitungen gemein, und wird darin durch die einfache Begleitung des Gesanges mit der Guitarre befestigt. Die Guitarre (Viola) ist auch hier, wie im südlichen Europa, das Lieblingsinstrument; dagegen gehört ein Fortepiano zu den seltensten Meubles und wird nur in reichen Häusern angetroffen.”

${ }^{10}$ Os Däniker-Halle viveram no Rio de Janeiro de 1828 a 1852. Ver Silva (2015, p.v).
} 
há várias descrições de eventos musicais ao ar livre onde o violão era tocado "com flauta ou canto a uma ou duas vozes” (SILVA, 2015, p. 308). O violão também estava presente em rodas de amigos da família Däniker-Haller e era usado no acompanhamento de cançóes espanholas (SILVA, 2015, p. 308-309 $)^{11}$. A família não apenas tocava viola no espaço doméstico, mas também interagia com profissionais do instrumento. Um registro no diário de Heinrich Däniker-Haller demonstra que Heinrich e o músico Bartolomeo Bortolazzi tocaram juntos em um ensaio de uma orquestra de músicos amadores. Na entrada de 28 de janeiro de 1831 o comerciante afirma: "Sexta-feira. Estive na sociedade musical e toquei com o violino do sr. Heckel. Bortolazzi tocou viola [guitar].”12 A família Däniker-Haller é, portanto, um exemplo documentado do uso do violão pela mais alta sociedade na primeira metade do século XIX no Rio de Janeiro.

A coexistência da viola e do violão, bem como o processo de re-significação destes dois instrumentos na primeira metade do século XIX são objetos de discussão bastante atual entre pesquisadores de instrumentos de cordas dedilhadas. ${ }^{13}$ Certamente novas análises baseadas em documentação ainda não discutida trarão luz sobre essas questões. O que se apreende é que instrumentos de cordas dedilhadas eram usados por negros e brancos, livres e escravizados, em espaço doméstico e público, por diletantes e profissionais. Por mais que se considere que provavelmente estes atores tocavam instrumentos distintos, com qualidade de feitura e, consequentemente, preços diferentes, ${ }^{14}$ não se pode afirmar que predominava o preconceito contra a viola ou o violão no final do século XVIII e início do XIX no Rio de Janeiro. Uma atitude predominantemente preconceituosa em relação a instrumentos de cordas dedilhadas dataria do último quarto do século XIX. ${ }^{15}$

\footnotetext{
${ }^{11}$ Silva se refere a entradas de abril de 1843.

12 "Friday. I was in the musical society, and played on Mr. Heckel's fiddle. Bortolazzi played the guitar." Ver Silva (2015, p. 305). Silva levanta a dúvida quanto ao músico a que Heinrich se refere ser Bartolomeo Bortolazzi ou seu filho, Giacomo Giusepe. Budasz (2015, p.96), revisando as informaçốes constantes do inventário de Catherina Margarida, primeira esposa de Bartolomeo, feito em 1821 constata que Giacomo Giusepe não é citado e conclui que não é possível saber ao certo o que havia sido dele àquela altura. Voltaremos a Bartolomeo Bortolazzi mais adiante.

${ }^{13}$ Para diferentes análises da transição da viola para o violão no espaço urbano, ver Taborda (2019, 2011, e 2011b, especialmente p. 53-57), e Castro (2007, p.26-27 e 2014, especialmente p. 13-20 e 296-304).

${ }^{14}$ Nogueira (2008, p. 27 e 62) dá exemplos documentados de violas de diferentes feituras e preços nos séculos XVII e XVIII.

${ }^{15}$ Taborda (2011b, p. 167-178) discute a questão dos conflitos socioculturais, especialmente em fins do século XIX e início do século XX, que fazem do violáo um instrumento ao mesmo tempo associado à vadiagem e ícone da expressão musical brasileira. Castro (2014, p. 171-172 e 302) dá um exemplo de romance do século XIX, A Moreninha, de Joaquim Manuel de Macedo (1844), no qual a viola é associado a um tipo rústico ou atrasado. Ele observa, porém, que não é possível determinar pelas fontes que analisou, se membros das classes mais abastadas teriam deixado de tocar viola àquela altura.
} 
No caso de José Maurício esse preconceito se manifesta na leitura que se faz da vida do compositor exatamente nesse período. Moreira de Azevedo, ao comentar sobre a atividade docente de José Maurício e o instrumento que usava para lecionar, ressalta a situação financeira precária do padre mestre: “... não podendo comprar um cravo, servia-se de uma viola de cordas metálicas para ensinar sua arte.” (AZEVEDO, 1877, p. 323) A viola é retratada como um índice da pobreza de José Maurício e como inferior ao cravo. Considerando o exposto sobre os espaços de circulação e uso dos instrumentos de cordas dedilhadas não é surpresa, muito menos demérito, que José Maurício não possuísse um instrumento de teclas. $\mathrm{Na}$ verdade esse fato decorre da realidade sociocultural do período. Há que se considerar que a viola era provavelmente um instrumento de uso regular na instrução musical profissionalizante nas primeiras décadas do século XIX a ponto de um importante curso de música, o de José Maurício, fazer uso dele.

O papel da viola no curso de música de José Maurício nos remete à presença do instrumento no ambiente de formação musical da época, não só profissional, mas diletante. No levantamento feito por Amorim (2017b) dos anúncios de aulas de música em periódicos do Rio de Janeiro entre 1808 e 1822 chama a atenção o nome de Manoel de Andrade e Almada. Único professor declaradamente de viola, explicitamente para acompanhamento, lecionava também língua estrangeira. Através de seu anúncio no Diário do Rio de Janeiro de 3 de setembro de 1821 ficamos sabendo que Almada oferecia "liçôes em sua casa a 3\$200; por casa de discípulos a 8 \$000. [...] A meninos em sua casa ensina a Música vocal a $2 \$ 000$ por mês”. Além de revelar a variedade nos preços cobrados para cada tipo de serviço, o anúncio também revela outros dados significativos: "Oferece-se também a dar lições por Música, ou sem ela, a quaisquer curiosos que para seu divertimento queiram tocar em Rabeca Valsas, Minuetes e Contradanças, ou acompanhar em Viola as mesmas peças a $4 \$ 800$ rs [réis] por mês” (AMORIM, 2017b, p. 50. Grifo nosso.). A oferta de aulas “por Música, ou sem ela” tanto em rabeca quanto em viola demonstra a existência de um público amador para as duas formas de aprendizado, letrado e iletrado. Não apenas a viola, mas também o violino, eram objeto de interesse dos dois tipos de público. Essa, pelo menos, parece ter sido a expectativa de Almada.

Outro nome a ser discutido aqui é o de Bartolomeo Bortolazzi (1772-1846), mencionado anteriormente em conexão com a família Däniker-Haller. Em 1826 Bortolazzi oferecia aulas de canto, viola, viola francesa e Mandolino. O músico seguia atuante em 1844, oferecendo aulas de canto e 
violão (BUDASZ, 2015, p. 103). No caso de Bortolazzi temos o registro de oferta de instrução em diferentes tipos de instrumentos de cordas dedilhadas, sugerindo que em 1826 haveria um público tanto para a viola francesa quanto para a viola de cinco ordens. Vale observar, também, que no espaço de pouco menos de vinte anos a viola francesa, ou violão, torna-se o único instrumento a figurar em seu anúncio, o que pode indicar uma maior difusão do instrumento de seis cordas entre o público alvo de Bortolazzi.

Uma ideia do repertório praticado por Bortolazzi é fornecida pela Colleç̧aó de Modinhas Brazileiras com Acompanham.to de Viola Franceza Composta por Bartholomeu Bortolazzi. Proffessor, e Compositor de Musica, Mestre de Canto, de Viola Franceza. A coleção foi localizada recentemente por Alberto Pacheco (2019) juntamente com uma segunda coleção de conteúdo e caligrafia similares, mas sem indicação de quem a compilou. Nenhuma das duas coleções está datada. Pacheco considera que a coleção sem autoria seja, provavelmente, de Bortolazzi também. Esta coleção contém uma modinha de José Maurício Nunes Garcia, Estas lagrimas sentidas, até então desconhecida. ${ }^{16}$ Tem-se, portanto, um exemplo de acompanhamento notado em viola francesa de uma modinha de José Maurício por um músico atuante no meio musical carioca nas décadas de 1820-1840.

Pode-se supor que boa parte da instrução oferecida por Bortolazzi em instrumentos de cordas dedilhadas fosse dedicada ao acompanhamento. ${ }^{17}$ Embora a parte de viola francesa no manuscrito de Estas lagrimas sentidas seja inteiramente notada, é preciso ter em mente que os exemplos de modinha notada são resultado de um processo de fixação de uma prática variável, visto que a performance da modinha compreendia muita improvisação tanto da música quanto da letra (PACHECO, 2019, p. 11). Nesse contexto é importante observar que tratados de baixo contínuo, que pertencem ao universo da música letrada, fazem referência à instrução para violeiros. ${ }^{18} \mathrm{~A}$ Nova Arte da Viola, de Manoel da Paixão Ribeiro (Coimbra, 1789), se propóe a ensinar a prática do acompanhamento.

\footnotetext{
${ }^{16}$ Para uma descrição dos manuscritos, ver Pacheco (2019, p.8-9). O autor fornece ainda uma edição crítica de todas as modinhas conhecidas de José Maurício, incluindo a recém-descoberta.

${ }^{17}$ Bortolazzi era um reconhecido virtuose do mandolino. Ver Budasz, (2015, p.82-85). Além disso, a prática documentada do período demonstra que os diversos tipos de viola eram instrumentos de acompanhamento.

${ }^{18}$ Tratados de baixo contínuo e acompanhamento dirigidos a cordas dedilhadas não são uma inovação de fins do século XVIII ou início do século XIX. Há obras com este fim desde o século XVII em diferentes idiomas. Para uma lista abrangente ver Fagerlande (2011, 144, nota 154). A questão aqui é verificar que as práticas em torno da viola de fins do século XVIII e início do XIX no âmbito português e brasileiro seguem figurando em tratados de baixo contínuo em língua portuguesa, incluindo tratados presentes em arquivos brasileiros. Dito de outra forma, o acompanhamento em viola a partir de um baixo, cifrado ou não, segue sendo praticado.
} 
Trata-se, claramente, da realização de um baixo contínuo, pois acompanhar é definido pelo autor como sendo a prática de "ajuntar-se ao baixo de cada signo as espécies convenientes para ficar mais cheio, mais forte, a fim de com este acompanhar-mos qualquer cantico, Rabéca, Frauta, \&c” (RIBEIRO, 1789, p. 43).

Na Estampa VII Ribeiro exemplifica, por meio de tablatura, como harmonizar uma escala ascendente de Sol maior e menor, uma fórmula conhecida como regra de oitava ${ }^{19}$. Note-se que além da tablatura ele fornece as Especies, ou os intervalos que compóem cada acorde.

FIGURA 1 - Trecho da Estampa VII, mostrando em tablatura como harmonizar a escala ascendente de Sol maior e menor. O autor esclarece: "As Linhas saô as cordas da Viola os numeros nellas postos significaó os pontos as cifras significaõ as cordas que se tocaõ soltas, as que naõ tem numeros ou cifras naô se tocaõ”

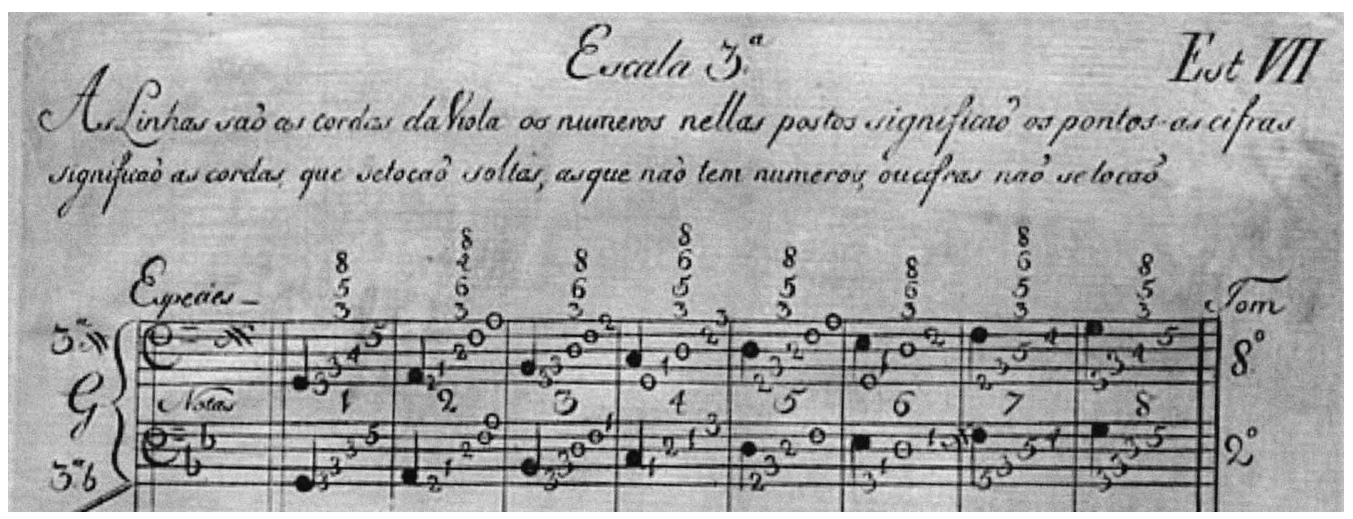

Fonte: RIBEIRO (1789, Estampa VII)

Na última estampa de seu tratado Ribeiro demonstra como "pôr por cifra” qualquer dança ou modinha. Primeiramente ele apresenta o Minuette do Mattos em partitura.

\footnotetext{
19 A expressão "regra de oitava” aparece pela primeira vez impressa no tratado de François Campion, Traité d'Accompagnement et de Composition selon la Rélgle des Octaves de musique, (Paris, 1716), mas a prática é certamente anterior e aparece em diferentes idiomas com terminologia variada. Ver Christensen, 1992.
} 
FIGURA 2 - Trecho da Estampa VIII, Minuette do Mattos.

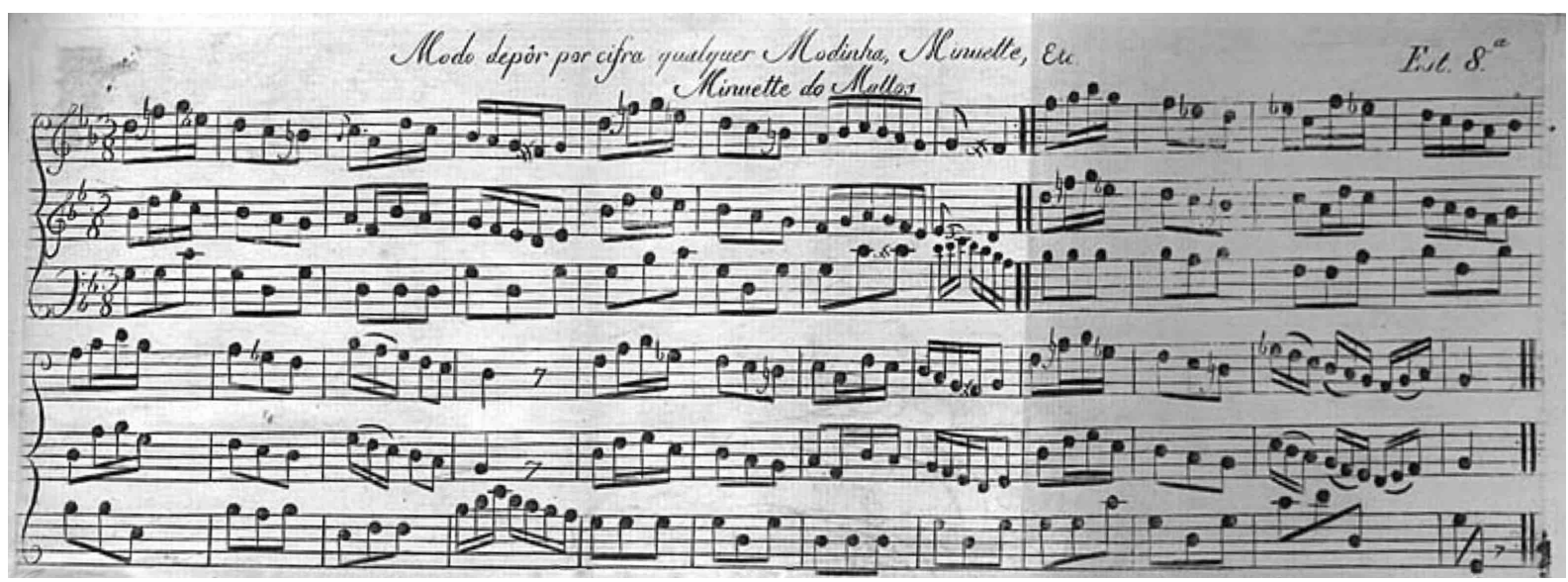

Fonte: RIBEIRO (1789, Estampa VIII)

Logo abaixo ele demonstra como realizar o acompanhamento em tablatura. ${ }^{20}$

FIGURA 3 - O Minuette do Mattos por cifra. Explicação do autor: "Para se pôr por cifra o dito Minuette, saberemos, que as Linhas contadas de baixo para sima saó as cordas da Viola q a Clave de $G$ se deve pôr na 3a Linha, q he propriamente $\mathrm{G}$ q os numeros significaó os pontos p1. pancada huma; $\mathrm{p} 2$. pancadas duas q as brancas significaô cordas tocadas soltas.”

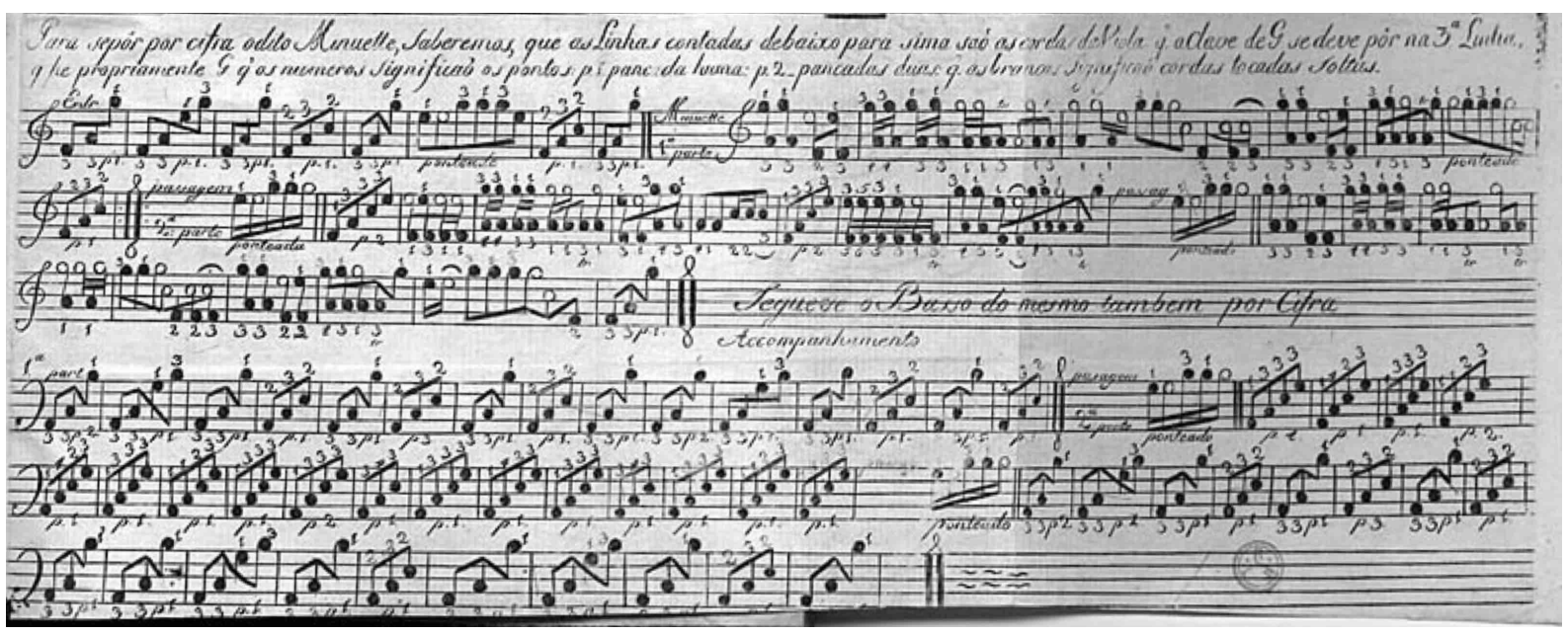

Fonte: RIBEIRO (1789, Estampa VIII)

O tratado de Ribeiro é uma fonte em língua portuguesa que ilustra bem como os aspectos práticos e teóricos do baixo contínuo são combinados no acompanhamento com a viola. Ao mesmo tempo em que, por meio de uma tablatura, demonstra como acompanhar, ele trata da construção

\footnotetext{
${ }^{20}$ Para uma tentativa de transcrição da tablatura de Ribeiro ver Nogueira (2008, p.140).
} 
dos acordes em termos da sobreposição das espécies. O tratado inclui, ainda, duas estampas em que se demonstram através de desenhos da mão no braço da viola como construir os acordes maiores e menores. Não há, no entanto, preocupação acerca da condução de vozes. O objetivo é fornecer ferramentas para que o Curiozo, como Ribeiro coloca, possa aprender com brevidade a acompanhar.

Quando consideramos os tratados de baixo contínuo em língua portuguesa em circulação no Brasil, constatamos que os instrumentos de cordas dedilhadas seguiam no instrumental do baixo contínuo no século XIX. Varella (Porto, 1806) inclui no seu Compendio de musica uma seção com Liçoens de acompan bamento em orgaó, cravo, guitarra, ou qualquer outro instrumento, em que se póde obter regular harmonia (FAGERLANDE, 2011, p. 143). ${ }^{21}$ E o autor anônimo da Arte de muzica que mencionamos acima tem claramente a guitarra em mente quando elabora seu tratado. ${ }^{22}$ Consideramos relevante ver em mais detalhe as diversas menções que este documento faz à guitarra e suas orientaçôes sobre o acompanhamento em instrumentos de cordas dedilhadas.

Logo no início de sua Arte, na explicação sobre as claves e sobre como ler as notas da pauta, o autor afirma: "e como a [clave de] de G, he a que compete á Guitarra, por tanto se mostrão todos os Signos, comprehendidos nos pontos, que tem a mesma Guitarra no seguinte”. (ANÔNIMO, 1823, $5-6)$

FIGURA 4 - Exemplo da extensão da guitarra

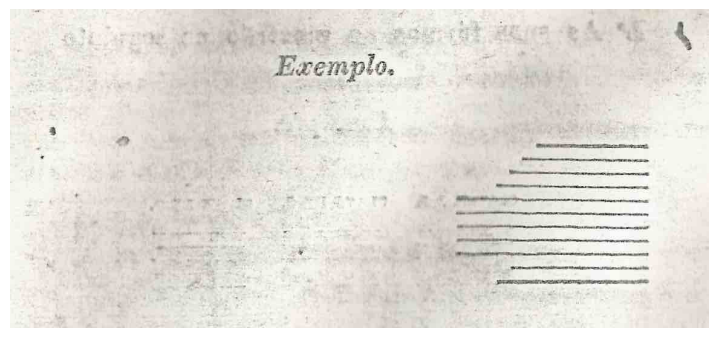

Fonte: ANÔNIMO (1823, p. 6)

\footnotetext{
${ }^{21}$ Os tratados da segunda metade do século XVIII analisados por Fagerlande não mencionam a viola, mas tampouco a excluem. O tratado de Alberto Joseph Gomes da Silva, Regras de acompanhar no cravo, ou orgão e ainda também para qualquer outro instrumento de vozes (Lisboa, 1758) e o de Francisco Ignacio Solano, Novo Tratado de Música, Metrica e Rythmica, o qual ensina a acompanhar no cravo, órgão, ou qualquer outro instrumento (Lisboa, 1779) estão direcionados a instrumentos de teclas, mas mencionam em seus títulos outros instrumentos harmônicos, o que incluiria os instrumentos de cordas dedilhadas. Ver Fagerlande (2011, p. 143).

${ }^{22}$ Fagerlande considera que o autor anônimo é o único dos tratadistas por ele pesquisado que direcionou seu manual para guitarristas. Todos os demais, apesar da constante menção a instrumentos harmônicos diversos, direcionam suas explicaçôes e exemplos para o cravo e o órgão. Ver Fagerlande (2011, p.143-144).
} 
O exemplo demonstra a pauta musical com as linhas suplementares superiores e inferiores, dentro da extensão da guitarra que serve de referência ao autor. Considerando a clave de sol na segunda linha, a extensão apresentada seria, da segunda linha suplementar inferior à quarta linha suplementar superior, Lá 2- Sol $5^{23}$.

O autor anônimo volta a mencionar a guitarra em sua explicação sobre as figuras musicais, quando esclarece: “As tres primeiras figuras [máxima, longa e breve] já se não usão na Muzica moderna, e muito principalmente na de Guitarra [...]” (ANÔNIMO, 1823, p. 9). Aqui ele sugere que a música de guitarra pertenceria a uma categoria à parte, no sentido de que seu repertório seria consideravelmente distinto daquele que, no passado, usava máxima, longa e breve em sua notação.

Em sua explicação sobre a escala musical a guitarra é novamente usada como referência: "Do Tom. Antes que se principie a tocar, deve-se conhecer o Tom; o qual he hum harmónico Compendio de sete differentes Intervallos, que se explicão tocando-se na Guitarra as cordas, a que pertencem os Signos C, D, E, F, G, A, B, C, a que chamão hum Diapasão.” (ANÔNIMO, 1823, p. 21) É interessante notar que o autor sugere que se demonstre na guitarra a escala, o que pode ser visto como mais um indício de que este instrumento era usado regularmente no ensino de música.

Ao final da Arte o autor justifica a inclusão de uma pequena explanação sobre baixo contínuo e acompanhamento pela necessidade de o tocador de guitarra saber acompanhar: "Do Accompanhamento. Como julguei ser tambem necessario, a que tóca, e estuda Guitarra, o saber accompanhar algumas Modinhas, Minuetes, e outras Peças deste genero, só pelo Basso Continuo; he por esta razão, que escrevi mais os seguintes Paragrafos, para lhes servirem de huma breve instrucção.” (ANÔNIMO, 1823, p. 24-25)

Desta forma a Arte de muzica, apesar de resumida, se diferencia das artinhas que tinham por objetivo principal instruir nos rudimentos de leitura e escrita musical. ${ }^{24}$ É significativo que essa diferenciação se dê pelo interesse em instruir os tocadores de instrumentos de cordas dedilhadas no acompanhamento a partir de um baixo. Deve-se considerar que a prática letrada do baixo contínuo em guitarra era suficientemente difundida para justificar a impressão de um manual.

\footnotetext{
${ }^{23}$ Usamos o Dó 3 como Dó central.

${ }^{24}$ Sobre as artinhas ver Binder; Castagna (1998, p. 20, nota 54).
} 
As explicações do autor anônimo sobre o baixo contínuo e o acompanhamento giram em torno da regra de oitava e da adequação desta à guitarra:

\begin{abstract}
Accompanhamento, he a execução de huma harmonica [sic] completa, e regular sobre hum Instrumento proprio a fazer esta harmonia, assim como o Orgão, o Cravo, a Tiorba, a Cithara, a Guitarra \&c. Porém como o Basso Continuo, juntamente com seus competentes Acordes, não se pódem dizer separados na Guitarra, e como nelle vejo, que só se poderá dizer huma destas, que ordinariamente são os Acordes, que se aplicão ás Notas do Basso continuo; por esta razão he que sem demora de tempo, vou tratar da applicação destes mesmos Acordes sobre as Notas, do mesmo Basso; circunstancia esta a mais necessaria, para o que quizer bem accompanhar. (ANÔNIMO, 1823, p. 25)
\end{abstract}

Não há, portanto, uma instrução quanto à condução de vozes, mas sim quanto à construção dos acordes adequados a cada grau da escala. O guitarrista deve se concentrar nos acordes visto que, na guitarra, não se pode tocar separados o baixo e o acompanhamento.

É interessante notar que o autor anônimo, em suas explicações sobre os termos "basso continuo" e "regra da oitava”, procura demonstrar que estas práticas estão inseridas em tradiçóes que remontam ao século XVII. Sobre o baixo contínuo, anônimo explica: "Basso Continuo, he huma das partes, a mais grave, e que dura pelo espaço de toda a Peça. O seu principal uso, alem de regular a harmonia, he de sustentar a voz, de conservar o Tom. Disem, que Lodovico Vianna, de quem nos resta hum Tratado, fôra o que no principio do derradeiro Seculo, as poz primeiramente em uso.” (ANÔNIMO, 1823, p. 24, nota 20) O autor certamente se refere a Lodovico da Viadana (15601627), compositor italiano que no prefácio dos seus 100 concerti ecclesiastici op. 12 (Veneza, 1602) deixou as primeiras instruções que se conhece sobre o baixo contínuo (VIADANA..., 2001). Já na explicação sobre a regra de oitava o autor esclarece que se trata de uma "formula harmonica publicada a primeira vez por Delaire em 1700, a qual na Marcha Diatonica do Basso, determina o Acorde conveniente a cada gráo do Tom, tanto de 3a. maior, como menor; e tanto subindo, como descendo.” (ANÔNIMO, 1823, p. 26, nota 25) Aqui o autor anônimo provavelmente está se baseando em uma informação equivocada de Rousseau, que atribuiu a Etienne Denis Delaire a invenção da regra de oitava em seu Traité d'accompagnement pour le théorbe et le clavessin (Paris, 1690) (DELAIR..., 2001). 
Após expor os acordes da regra o autor explica como reduzí-los para uso na guitarra. ${ }^{25}$ Visto que os acordes da regra "pertencem mais ao Basso Continuo, e são mais proprios para o Cravo, do que para a Guitarra, devemos saber, que a postura que se der na Tonica fundamental que he a 1.a Nota do Tom, será a mesma que competirá á 3.a; e 8.a, e á 5.a quando vier numerada com 4-6.” O mesmo acorde que se aplica à tônica pode ser aplicado também ao $3^{\circ}$ grau da escala e ao $5^{\circ}$ grau quando este estiver na segunda inversão. A seguir esclarece os graus em que se pode usar o acorde de dominante: “A postura, que se der na Dominante, que he a 5.a do Tom, será a mesma que competirá á 2.a, e 7.a do mesmo Tom; e á 4.a quando vier depois da 5a. accompanhada com 2.a, e 4.a.” Pode-se usar, portanto, o mesmo acorde de dominante nos $2^{\circ}$ e $7^{\circ}$ graus e no $4^{\circ}$ grau com cifra $2-4$, o que resulta na terceira inversão do acorde de sétima da dominante. Por fim "A postura, que se der na SubDominante, que he a 4.a do Tom, quando vier accompanhada com a 3.a, e 5.a, será a mesma que competirá á 6.a”, ou seja, sobre o $6^{\circ}$ grau pode-se usar o mesmo acorde que se emprega sobre o $4^{\circ} . \mathrm{O}$ autor harmoniza, portanto, a escala inteira com três acordes (de tônica, subdominante e dominante) e acrescenta que isso sempre se pode fazer quando não haja outras cifras que peçam um acorde diferente. $\mathrm{O}$ autor uma última vez justifica seu método a partir de questões não apenas práticas, mas também estilísticas: “[...] a Guitarra não póde dizer o Basso Continuo, e dizendo-o não causa o preciso effeito; por este motivo, he que reduzi ás referidas porturas, os [sic] Notas da Escála do mesmo Basso Continuo, que serviráó de Norte, para o que quizer accompanhar neste Instrumento algumas Modinhas, Minuetes.” Há, portanto, a questão do efeito que a guitarra causa no acompanhamento e dos tipos de peças que se pode acompanhar com essa técnica.

O tipo de acompanhamento ensinado por Ribeiro e pelo autor anônimo poderia ser aplicado a modinhas como Ninguem morra de siúme, que integra a coleção Modinhas do Brazil, depositada na Biblioteca da Ajuda em Lisboa (BUDASZ, 2007, p. 17-19). Aqui o baixo cifrado exemplifica a junção entre o acompanhamento de modinhas na viola e o baixo contínuo.

\footnotetext{
${ }^{25}$ Todas as citações deste parágrafo são da Arte de muzica, p. 31.
} 
FIGURA 5 - Trecho da Modinha Ninguem morra de siume, autor desconhecido. Modinhas do Brazil, Lisboa, Biblioteca da Ajuda.

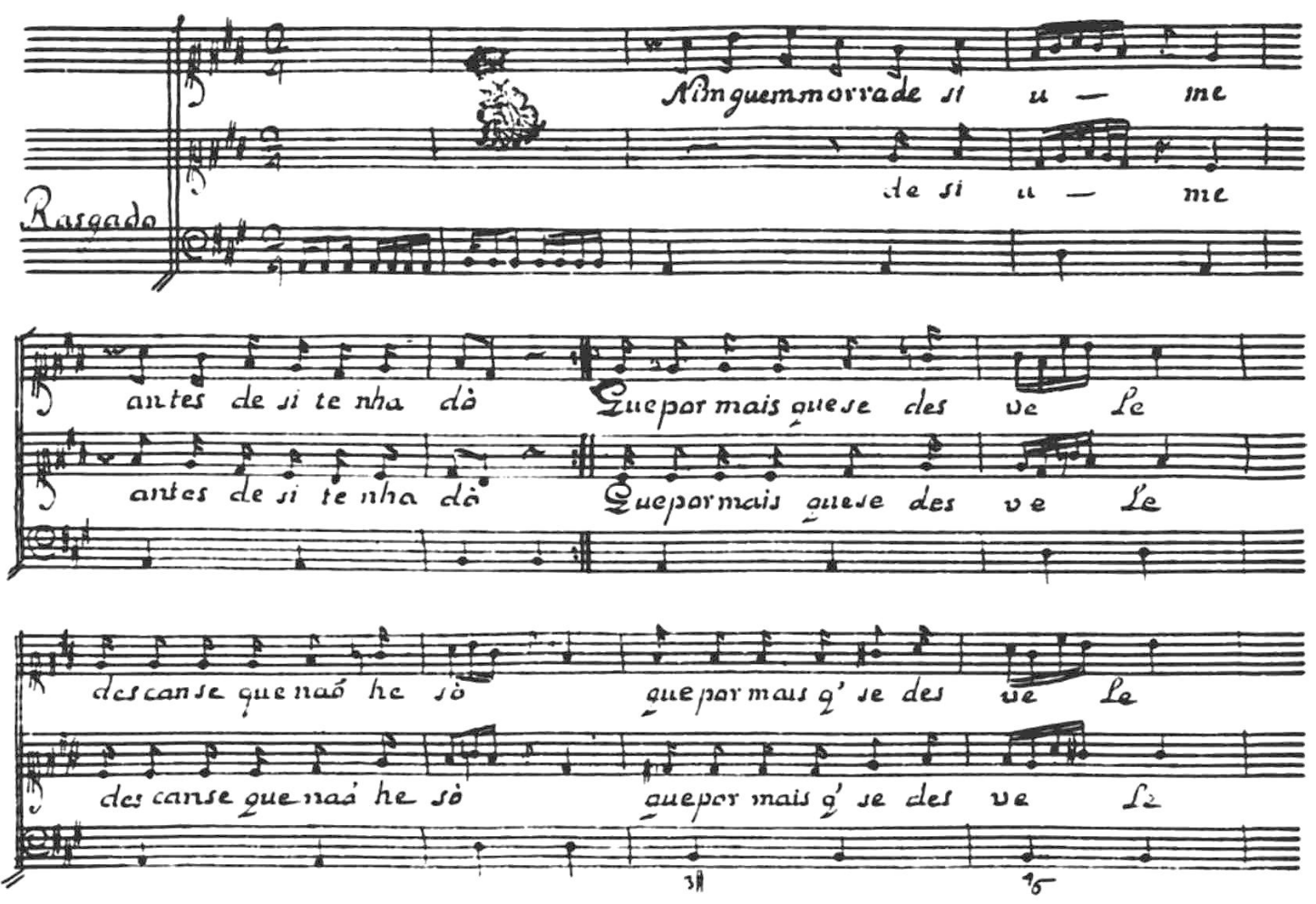

Fonte: BUDASZ (2007, p. 17)

Vê-se, portanto, que a viola representa níveis muito contrastantes de significação no período. Sua associação com escravizados não impedia sua ampla difusão, mantendo-se mesmo objeto de interesse de classes letradas. $\mathrm{O}$ instrumento tem relevância na dinâmica do ensino de música do período, tanto amador quanto profissional. Isso fica claro tanto pelo conteúdo dos tratados de Ribeiro (1789) e Anônimo (1823) quanto pelo tipo de instrução oferecido por Almada no Rio de Janeiro. De fato, Almada ensinava a tocar em rabeca e a acompanhar em viola valsas, minuetos e contradanças, repertório semelhante ao usado por Ribeiro em seus exemplos e ao descrito pelo autor da Arte de muzica. Ribeiro, além do Minuette de Mattos, reproduz também em seu tratado o Minuette da Rozinha, Contra Rozinha e a modinha Marilia bella vou retratarte, do compositor português Joze Mauricio. O anônimo menciona a modinha e o minuete como exemplos de peças que se pode acompanhar usando suas instruções.

A prática do baixo contínuo e as especificidades da viola nessa prática nos permitem entender aspectos técnicos da realização do acompanhamento em instrumentos de cordas dedilhadas do 
período. Elas revelam, também, significados residuais e latentes da prática musical da época. Há, por um lado, a manutenção da instrução sobre como acompanhar a partir de um baixo e como construir e encadear acordes a partir da sobreposição de intervalos, tanto na Nova arte de viola quanto na Arte de muzica. Além disso, as explicações dos termos basso continuo e regra de oitava, ancorando-os na tradição dos tratados de acompanhamento, também podem ser vistos como aspectos residuais de uma técnica que floresceu nos séculos XVII e XVIII. Há, por outro lado, a simplificação da regra de oitava, com sua redução a três acordes, como recomendado na Arte de muzica. Neste caso específico fica claro o processo de ressignificação da prática do baixo contínuo no contexto da instrução sobre acompanhamento em cordas dedilhadas no primeiro quarto do século XIX no Rio de Janeiro.

A análise de alguns exemplos notados de acompanhamento permite um conhecimento mais efetivo da linguagem musical do período e, possivelmente, do tipo de ambiência sonora que os instrumentos de cordas dedilhadas ajudaram a criar. Um breve resumo das técnicas levantadas propiciará, esperamos, material para aqueles interessados em reconstruir essa prática hoje. Ele possibilitará também uma aproximação maior com os conflitos em torno destes instrumentos e com seu uso na formação musical de então.

\section{Exemplos de acompanhamento à viola: simplificações de uma prática improvisatória.}

Exemplos notados de acompanhamento, já sejam em partitura ou tablatura, geralmente resultam em uma simplificação da prática que estão querendo representar. ${ }^{26}$ Apesar dessa limitação, são esses exemplos que fornecem aquilo que ficou fixado dessa prática. Um elemento recorrente nos exemplos analisados é o uso de diferentes figurações harmônicas - arpejos ascendentes, basso d'Alberti, outros desenhos de acordes quebrados - além de acordes em bloco. Os quatro exemplos a seguir são todos de acompanhamentos de modinhas, os três primeiros do Jornal de Modinhas publicado em Lisboa entre 1792 e 1796, e o último da coleção Modinhas do Brazil. ${ }^{27}$ Eles demonstram algumas das fórmulas usadas em fins do século XVIII.

\footnotetext{
${ }^{26}$ Nogueira (2008, p.40-44) chama a atenção para o caráter modesto dos arranjos publicados na época, considerando que são demasiadamente simplificados e padronizados e que não exploram as possibilidades idiomáticas dos instrumentos.

${ }^{27}$ Para uma lista das modinhas publicadas pelo Jornal de Modinhas ver anexo na edição facsimilar de 1996.
} 
FIGURA 6 - Trecho de acompanhamento da modinha Amor concedeu m'um premio, de Antonio da Silva Leite, para viola e duas guitarras. Jornal de Modin has, ano II, 1793-1794.

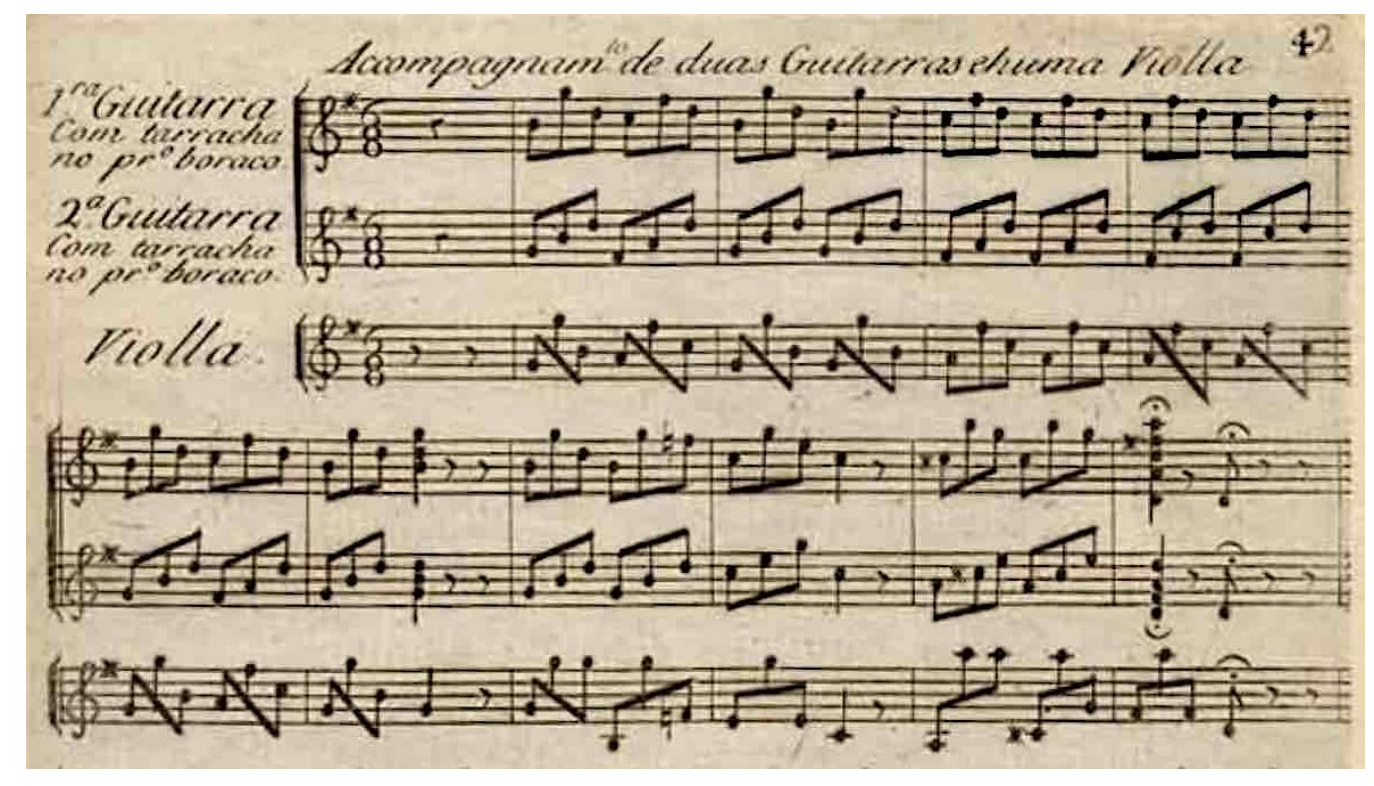

Fonte: NOGUEIRA (2008, p. 42)

FIGURA 7 - Emproviso com acompanhamento para viola Já gozei da liberdade, de Jose Roiz de Jezus. Jornal de Modinhas, ano IV, 1795-1796.

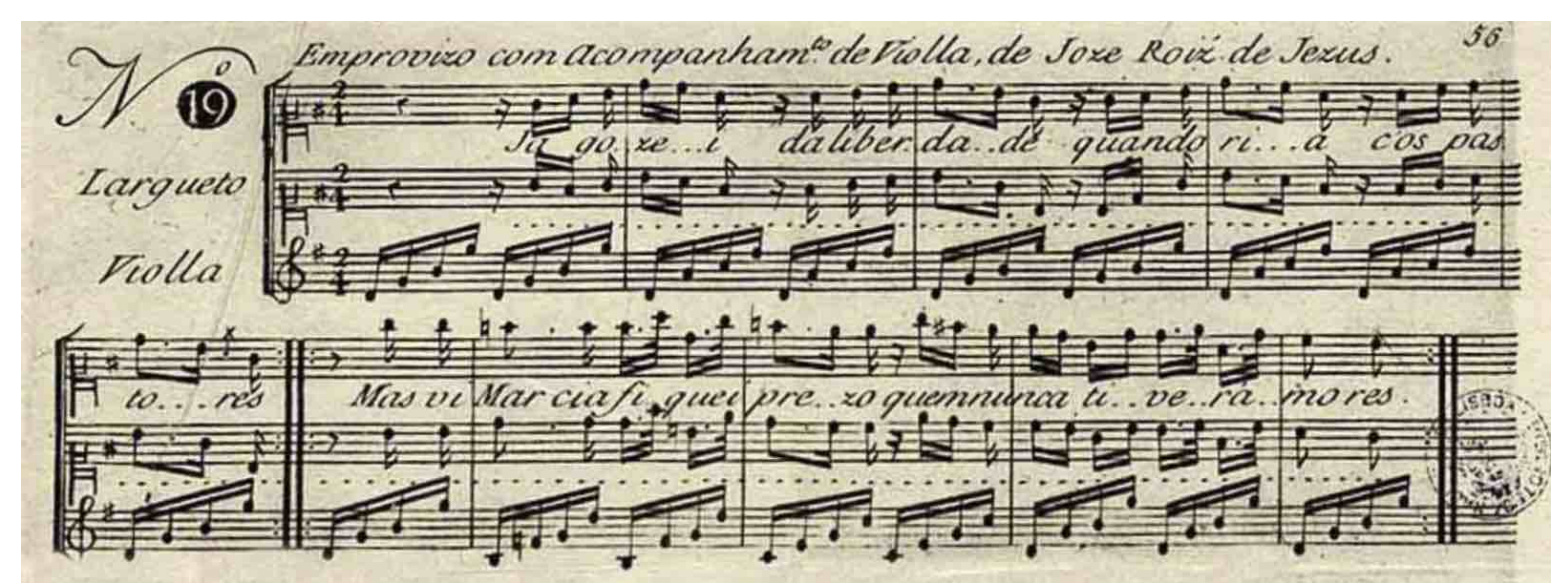

Fonte: NOGUEIRA (2008, p. 44). 
FIGURA 8 - Acompanhamento de guitarra a solo da modinha Tempo que breve passaste, de Antonio da Silva Leite. Jornal de Modinhas, ano II, 1793-1794. Note-se o contraste no acompanhamento das duas seçôes, a primeira em 3 alterna basso d'Alberti e acordes, a segunda em 2 (Allegreto) majoritariamente em acordes.

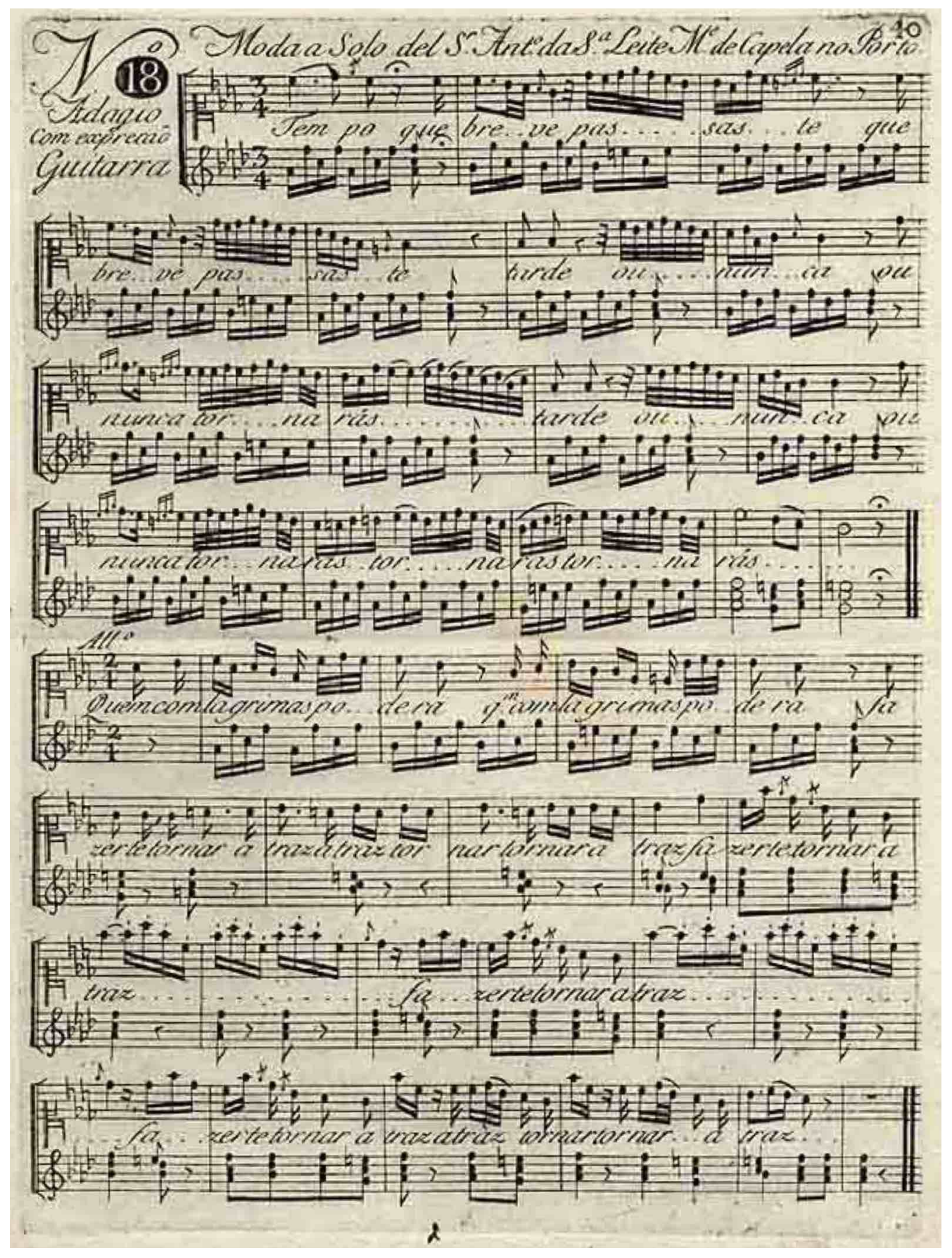

Fonte: NOGUEIRA (2008, p. 45). 
FIGURA 9 - Trecho da modinha brasileira Eu nasci sem coração, com acompanhamento de viola. Texto de Domingos Caldas Barbosa e música de autor desconhecido. Modinhas do Brazil, Lisboa, Biblioteca da Ajuda.

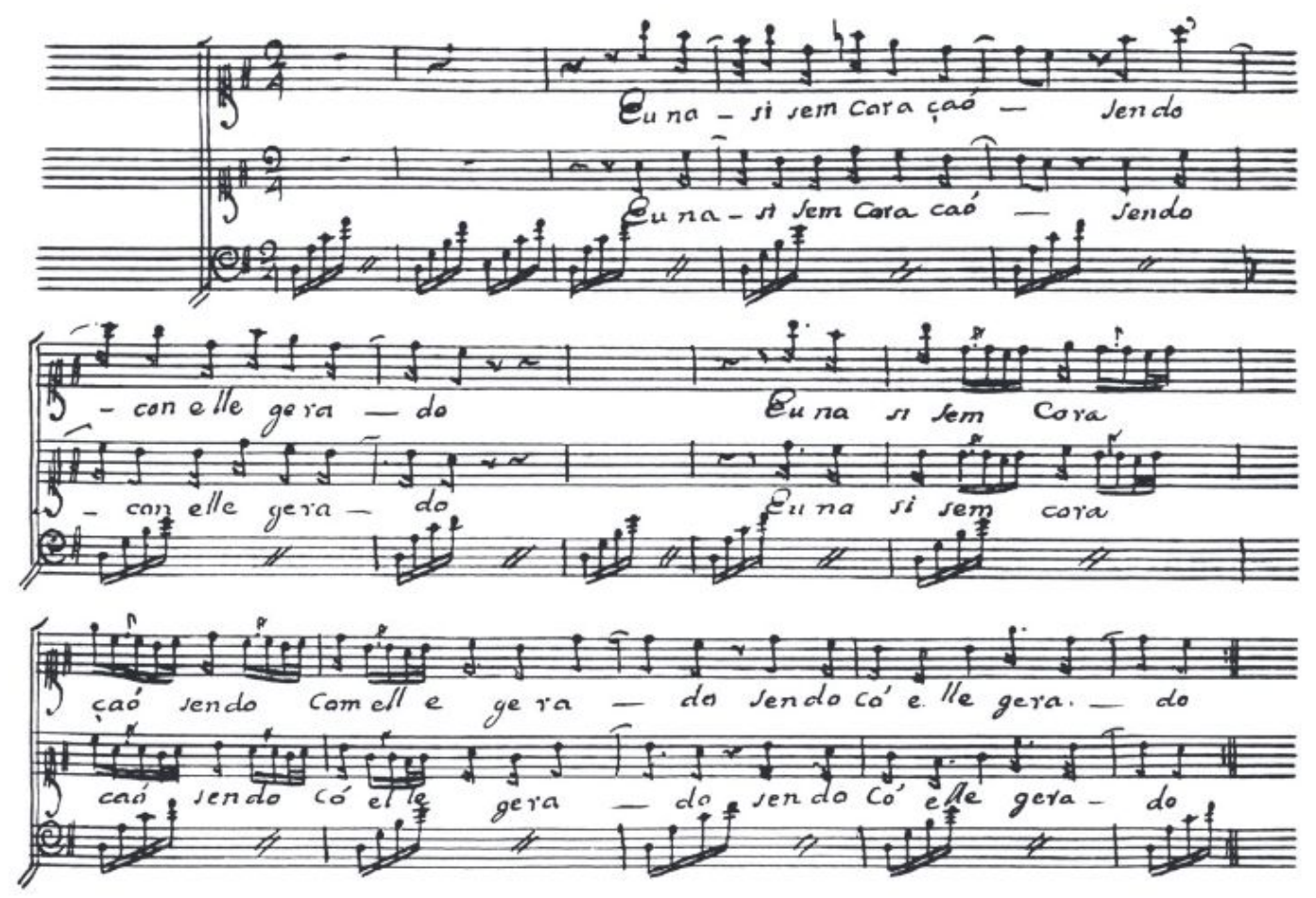

Fonte: BUDASZ (2007, p. 18).

Um último exemplo a comentar aqui é o do acompanhamento para viola francesa da modinha Estas lágrimas sentidas, do Pe. José Maurício, parte da Colleç̧ão de modinhas brazileiras mencionada na seção anterior. Não se trata, logicamente, de um baixo contínuo propriamente dito, mas sim de um acompanhamento que é parte de uma tradição improvisatória e, como tal, guarda, possivelmente, semelhanças com o acompanhamento que se praticava a partir de um baixo.

Observa-se que o acompanhamento mescla figuraçóes com acordes quebrados (como no compasso 9), arpejos (cc. 8, 10 e similares) e acordes em bloco (c.11) (Figura 10). 
FIGURA 10 - Estas lágrimas sentidas, compassos 8-11, de José Maurício Nunes Garcia, da Collecção de modinhas brasileiras com acompanhamento de viola franceza compoziçaó de varios autores, edição crítica de Alberto Pacheco.
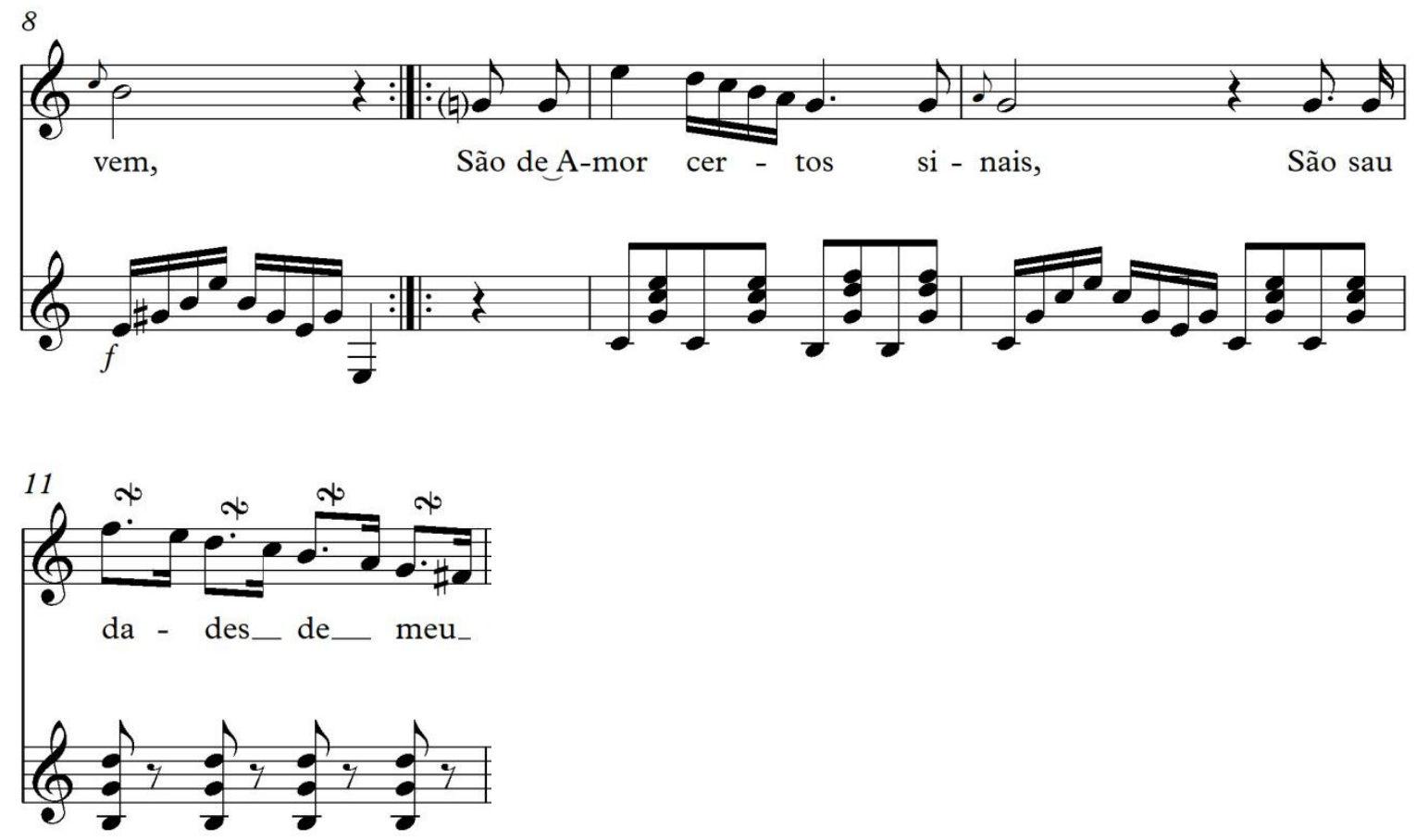

Fonte: PACHECO (2019, p. 50)

Trata-se de padrões rítmicos e texturas presentes nas demais fontes analisadas. Esses padrôes, contudo, são usados de forma mais variada, ressaltando contornos rítmicos da voz superior, como no c.11, preenchendo silêncios da voz solista, como no c. 12, explorando silêncios no acompanhamento como nos compassos 13-14, ou ainda funcionando como resposta à pergunta da voz solista, como nos cc. 13-15 (Figura 11).

FIGURA 11 - Estas lágrimas sentidas, compassos 11-16.

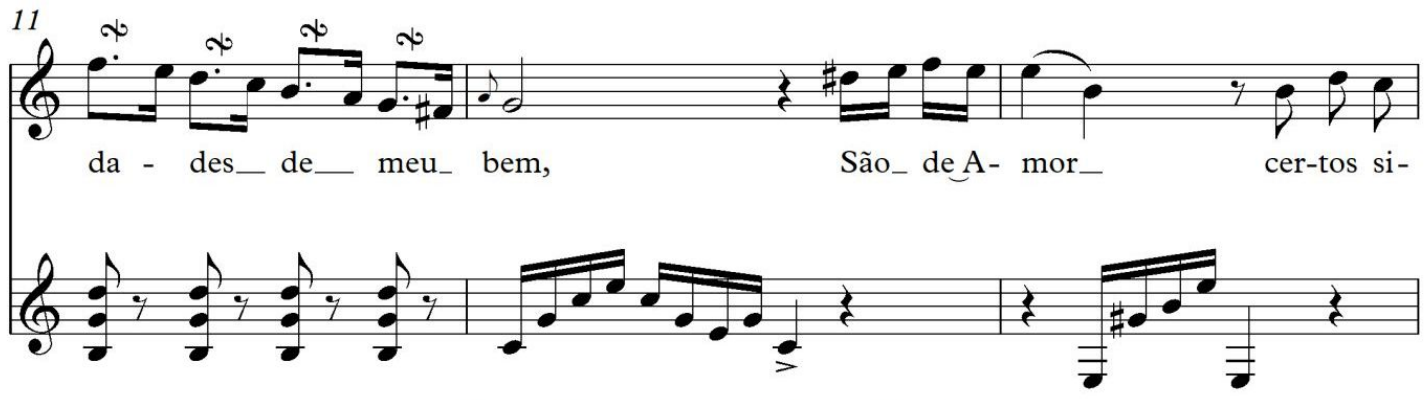


FIGURA 11 - (cont.) Estas lágrimas sentidas, compassos 11-16.

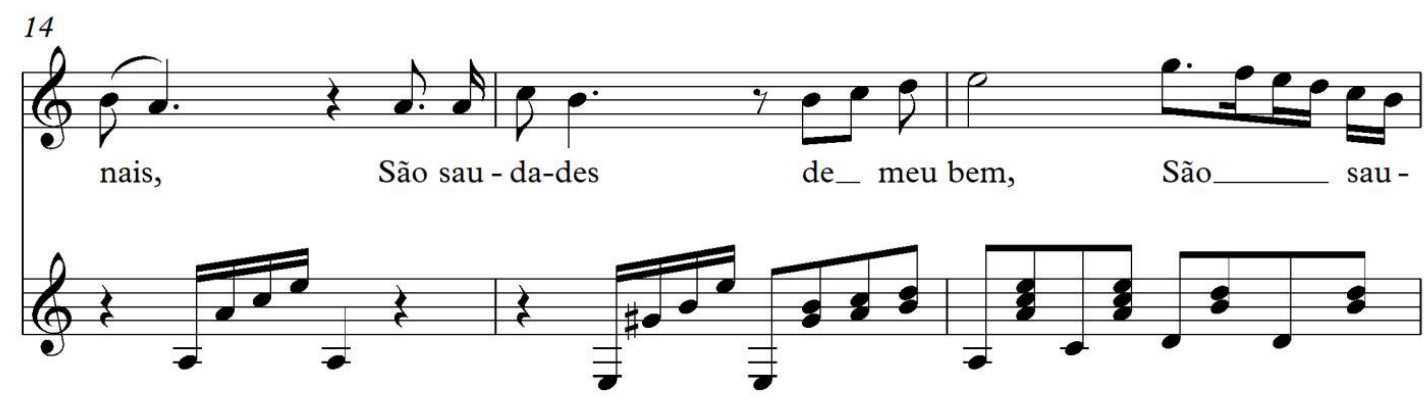

Fonte: PACHECO (2019, p. 50-51)

Um outro diferencial em relação aos acompanhamentos exemplificados anteriormente é a inserção na voz superior do acompanhamento de movimento melódico dobrando a voz solista. Nos compassos 5-6 o soprano do acompanhamento é uma versão não ornamentada da linha do canto nas sílabas “lágrimas sentidas” (Figura 12).

FIGURA 12 - Estas lágrimas sentidas, compassos 1-7.

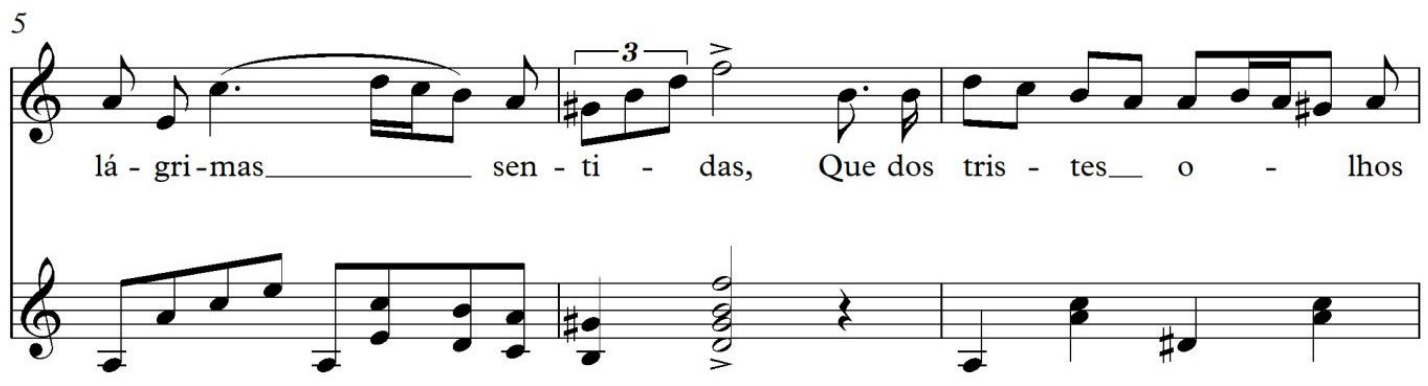

Fonte: PACHECO (2019, p. 50-51)

Temos, sem dúvidas, um acompanhamento mais variado do que os dos exemplos anteriores. É preciso ter em mente, no entanto, que publicaçóes como o Jornal de Modinhas atingiam um público muito mais amplo e forneciam música para uma clientela majoritariamente amadora. Além disso, a improvisação era regra e não exceção. Isto posto, pode-se afirmar que o acompanhamento, em geral, é mais dialogado do que os dos exemplos anteriores. As figurações são usadas de maneira a dar suporte rítmico à voz solista, preencher espaços deixados vazios pelo canto, ressaltar silêncios e responder à voz cantada. Deve-se, ainda, considerar a possibilidade de que violeiros profissionais, ou mesmo amadores habilidosos, tenham usados técnicas similares quando acompanhavam de um baixo apenas. 


\section{Considerações finais}

A partir de uma análise das muitas formas de representação e circulação dos instrumentos de cordas dedilhadas no Rio de Janeiro de finais do século XVIII e primeira metade do XIX é possível perceber alguns elementos que sugerem a importância e abrangência, do ponto de vista social e estético, da prática de baixo contínuo e do acompanhamento nestes instrumentos. Os instrumentos de cordas dedilhadas eram usados por pessoas de diversas classes sociais, tanto homens como mulheres, majoritariamente para acompanhar e a prática do acompanhamento gerou publicaçóes específicas, inclusive a primeira obra de instrução musical impressa no Brasil de que temos conhecimento.

As propostas de realização do baixo analisadas aqui certamente se aproximam da esfera letrada dessa prática: são fontes musicais notadas que, por si só, já resultaram de convenções e simplificações da improvisação praticada então. Do ponto de vista técnico, os exemplos apresentam a recorrência de diferentes figuraçốes harmônicas, tais como arpejos ascendentes, basso d'Alberti, outros desenhos de acordes quebrados, além de acordes em bloco. Um exemplo mais elaborado de acompanhamento nos permite perceber que a variedade de figurações e o uso de contornos rítmico-melódicos mais diversificados também eram elementos explorados pelos violeiros.

A relevância da viola para a instrução musical nas primeiras décadas do século XIX no Rio já havia sido atestada pelo uso deste instrumento no curso de música de José Maurício. Deve-se considerar que a ampla difusão da viola e de seu repertório pudessem ter feito dela um dos instrumentos de referência para o aprendizado de leitura e escrita musical. A recomendação, na Arte de muzica, de que se demonstrasse as notas musicais na guitarra é um indício disso.

As informações documentais sobre a prática de baixo contínuo em instrumentos de cordas dedilhadas analisadas aqui indicam a possibilidade de que, pelo menos no âmbito letrado, a instrução oferecida em princípios do século XIX seguisse calcada em uma tradição que remonta à primeira metade do século anterior. Há, contudo, a ressignificação dessa prática por meio da formulação de uma regra de oitava simplificada, harmonizada apenas com três acordes. Pode-se especular que a Arte de muzica possivelmente documente uma prática oral difundida na época, que atendia a um interesse 
por um uso mais imediato do instrumento. Teríamos, assim, mais um indício de aproximação entre as práticas oral e formal com instrumentos de cordas dedilhadas no período.

\section{AGRADECIMENTOS}

Ao Programa Institucional de Bolsas de Iniciação Científica Pibic / UFPE / CNPq pelo apoio financeiro à pesquisa que gerou este artigo.

\section{REFERÊNCIAS}

AMORIM, Humberto. “A carne mais barata do mercado é a carne negra”: comércio e fuga de escravos músicos nas primeiras décadas do Brasil oitocentista (1808-1830). Opus, v. 23, n. 2, p. 89, $2017 \mathrm{a}$.

AMORIM, Humberto. O ensino de música nas primeiras décadas do Brasil oitocentista (18081822). Opus, v. 23, n. 3, p. 43, 2017b.

ANÔNIMO. Arte de muzica para uzo da mocidade brazileira por bum seu patricio. Rio de Janeiro: Tipographia de Silva Porto, 1823.

AZEVEDO, Moreira de. O Rio de Janeiro: sua historia, monumentos, homens notaveis, usos e curiosidades. Rio deJaneiro: B.L. Garnier, 1877. v. 1.

BALLESTÉ, Adriana Olinto. Viola? Violão? Guitarra? Proposta de organização conceitual de instrumentos musicais de cordas dedilhadas luso-brasileiros no século XIX. 2009. $316 \mathrm{f}$. Tese (Doutorado em música). Centro de Letras e Artes, UNIRIO, Rio de Janeiro, 2009.

BARROSO, Maria Aída Falcão Santos. Ornamentação e improvisação no método de pianoforte de José Mauricio Nunes Garcia. 2006. 175 f. Dissertação (Mestrado em música). Escola de Música, Universidade Federal do Rio de Janeiro, Rio de Janeiro, 2006.

BINDER, Fernando Pereira; CASTAGNA, Paulo. Teoria Musical no Brasil: 1734-1854. 1998, Curitiba: Fundação cultural de Curitiba, 1998. p. 198-217.

BUDASZ, Rogério. Bartolomeo Bortolazzi (1772-1846): mandolinist, singer, and presumed carbonaro. Revista portuguesa de musicologia, v. 2, n. 1, p. 79-134, 2015.

BUDASZ, Rogério. Black guitar-players and early African-Iberian music in Portugal and Brazil. Early Music, v. 35, n. 1, p. 3-22, 2007.

BUDASZ, Rogério. The Five-Course guitar (viola) in Portugal and Brazil in the late seventeenth and early eighteenth centuries. 2001. 419 f. Tese (PhD). University of Southern California, 2001.

CASTRO, Renato Moreira Varoni de. Os caminhos da viola no Rio de Janeiro do século XIX. 2007. 113 f. Dissertação (Mestrado em música). Escola de Música, Universidade Federal do Rio de 
Janeiro, Rio de Janeiro, 2007.

CASTRO, Renato Moreira Varoni de. Towards a classificatory organology of the viola and the violão in nineteenth-century Rio de Janeiro. Revista Brasileira de Música, v. 29, n. 1, p. 125-147, 2016.

CASTRO, Renato Moreira Varoni de. Tuning in to the past: the viola and its representations in 19th century Rio de Janeiro. 2014. 327 f. Tese (PhD). School of History and Anthropology, Queen's University, Belfast, 2014.

CHRISTENSEN, Thomas. The Règle de l'Octave in thorough-bass theory and practice. Acta Musicologica, v. 64, p. 91-117, 1992.

DELAIR, ETIENNE DENIS. In: FULLER, David. Grove Music Online. Oxford: Oxford University Press, 2001. Disponível em:

$<$ https://www.oxfordmusiconline.com/grovemusic/view/10.1093/gmo/9781561592630.001.000 1/omo-9781561592630-e-0000007435>. Acesso em: 20 nov. 2020.

FAGERLANDE, Marcelo. O baixo contínuo no Brasil 1751-1851: os tratados em português. Rio de Janeiro: 7 Letras/Faperj, 2011.

FAGERLANDE, Marcelo. O método de pianoforte de José Mauricio Nunes Garcia. Rio de Janeiro: Relume Dumará, 1995.

FREIRE, Vanda Lima Bellard. A História da Música em questão - Uma reflexão metodológica. Fundamentos da Educação musical, v. 2, 1994.

Jornal de modinhas: ano I. Lisboa: Instituto da Biblioteca Nacional e do Livro, 1996.

MATTOS, Cleofe Person de. José Mauricio Nunes Garcia: biografia. Rio de Janeiro: Fundação Biblioteca Nacional, 1997.

NOGUEIRA, Gisela Gomes Pupo. A viola con anima: uma construção simbólica. 2008. $241 \mathrm{f}$. Tese (Doutorado em interfaces sociais da comunicação). Escola de comunicação e artes, Universidade de São Paulo, São Paulo, 2008.

PACHECO, Alberto José Vieira. As Modinhas do Pe. José Maurício Nunes Garcia: fontes, edição e prática. Per Musi, v. 39, n. 39, 2019.

RIBEIRO, Manoel da Paixão. Nova arte de viola. Coimbra: Real Officina da Universidade, 1789.

SILVA, Walter Luiz da. Heinrich e Cécile Däniker-Haller - A música doméstica na vida de um casal de negociantes suiços entre Zurique e o Rio de janeiro na primeira metade do século XIX. 2015. $371 \mathrm{f}$. Tese (Doutorado em musicologia histórica). Universidade Nova de Lisboa, Lisboa, 2015.

SPIX, Johann Baptist Von; MARTIUS, Karl Friedrich Philipp Von. Reise in Brasilien. 2a. ed. Augsburg: George Jaquet's, 1854.v. 1.

STAUNTON, George. An authentic account of an embassy from the King of Great Britain to the Emperor of China. Londres: C. Nicol, 1797. v. 1.

TABORDA, Marcia. Da viola à viola grande: a trajetória do violão no século XIX. In: LOPES, Antonio Herculano et al. (Org.). Música e história no longo século XIX. Rio de Janeiro: Fundação Casa de Rui Barbosa, 2011a. v. 12. p. 183-208. 
TABORDA, Marcia. O violão na agenda musical carioca oitocentista. OPUS, v. 25, n. 1, p. 56, mar. 2019.

TABORDA, Marcia. Violão e identidade nacional: Rio de Janeiro 1830-1930. Rio de Janeiro: Civilização Brasileira, 2011b.

TRILHA, Mário Marques. A música para tecla do Padre José Maurício Nunes Garcia (1767-1830). Per Musi, v. 39, n. 39, 2019.

VIADANA [GROSSI DA VIADANA], LODOVICO. In: MOMPELLIO, Federico. Grove Music Online. Oxford: Oxford University Press, 2001. Disponível em: <https://www.oxfordmusiconline.com/grovemusic/view/10.1093/gmo/9781561592630.001.000 1/omo-9781561592630-e-0000029278>. Acesso em: 13 nov. 2020.

\section{SOBRE AS AUTORAS}

Luciana Câmara Queiroz de Souza é bacharela e mestra em música pela Universidade Federal do Rio de Janeiro. Mestra em instrumentos históricos de teclas pela Escola Superior de Música de Freiburg, Alemanha. Doutora em musicologia pela Universidade de Glasgow, Reino Unido. Desde 2009 é professora de cravo e baixo contínuo do Departamento de Música da Universidade Federal de Pernambuco em Recife, Brasil. Tem especial interesse pela música do século XVII e pelas interfaces entre performance musical, história sócio-cultural e filosofia. Tem se apresentado como solista e camerista em várias cidades do Brasil. ORCID: https://orcid.org/0000-0002-5119-7531. E-mail: camara.lu@gmail.com

Andrea Alencar Coelho da Silva é bacharela em música - violão - pelo Departamento de Música da UFPE. Foi bolsista PIBIC/CNPq 2018-2019 com o projeto “A viola no Brasil no início do século XIX: sua inserção social e a prática de baixo contínuo”. Participou do III, IV e V Seminários de Violão José Carrión, realizados em Recife- PE entre 2014 e 2018; participou também do I Encontro Nordestino de Violonistas realizado em Recife-PE, do festival V Gramado in Concert - RS e do Festival de violão da UFRGS em 2019, onde fez masterclass com a violonista Berta Rojas. Atualmente é monitora de violão erudito pela Rede Municipal de Núcleos Musicais de Goiânia-GO. ORCID: https://orcid.org/0000-0003-0367-4003. E-mail: andreaalencar3@gmail.com 